\title{
Formación in vitro de rizomas en caña flecha (Gynerium sagitatum Aubl.) y recuperación de plantas
}

\author{
Arrow cane (Gynerium sagitatum Aubl.) in vitro rhizome formation \\ and plantlet recovery
}

\author{
Isidro E. Suarez*, Orlis Ortiz², Claudia M. López ${ }^{3}$ \\ Recibido para publicación: Julio 28 de 2016 - Aceptado para publicación: Abril 18 de 2017
}

\begin{abstract}
RESUMEN
La caña flecha Gynerium sagitatum Aubl. (Poaceae) es una especie de gran importancia ambiental, cultural y económica para ciertas comunidades indígenas del Norte de Colombia, empleando su fibra en la fabricación apreciables artesanías. La cosecha de la planta y la no reposición de esta, viene contribuyendo en la disminución de poblaciones naturales de la esta especie. La micropropagación ha emergido como una de las la única posibilidades de producir de forma eficiente material vegetal para el establecimiento de cultivos y restaurar zonas afectadas. Con el fin de mejorar la eficiencia económica del protocolo de micropropagación, estructuras del tipo rizomas fueron inducidas in vitro a partir de explantes consistentes de plantas stablecidas in vitro bajo tres niveles de sacarosa, cuatro de benzilaminopurina - BAP y cuatro de ácido abscísico - ABA en MS con (en mg $\mathrm{L}^{-1}$ ) myo-inositol $(100)$, tiamine $\mathrm{HCL}(0,4)$ y solidificados con Phytagel ${ }^{\circledR}$ (3.000). Los tratamientos (48) fueron distribuidos con un diseño completamente al azar con seis repeticiones por tratamiento. Los cultivos fueron mantenidos durante ocho semanas a $25{ }^{\circ} \mathrm{C}$ con $12 \mathrm{~h}$ de fotoperíodo $\left(40 \mu \mathrm{mol}\right.$ fotones $\left.\mathrm{m}^{-2} \mathrm{~s}^{-1}\right)$ suministrada con lámparas de luz fría fluorescente. Diferencias estadísticas se observaron con respecto al número de rizomas formados y longitud de los rizomas como efecto de la interacción de los tres factores. La recuperación de las plantas ex vitro ocurrió en mayor número $(6,0)$ cuando los rizomas se desarrollaron en medios suplidos con $263000 \mu \mathrm{M}$ de sacarosa combinado con 4,44 y $8,88 \mu \mathrm{M}$ de Benzilaminopurina - BAP. Los resultados evidencian la posibilidad de inducir in vitro rizomes de caña flecha para ser utilizados en conservación y propagación de esta especie.
\end{abstract}

Palabras clave: Caña flecha, micropropagación, in vitro, formación de rizomas, RCV.

\begin{abstract}
Gynerium sagitatum Aubl. (Poaceae) is an important environmental, cultural and economic species for aboriginal communities in Northern Colombia, in which the centrale central nerve is used to make precious craftsmanship products. The massive use of the plant with no restoration has dangerously decreased natural populations. Micropropagation has emerged as a way to efficiently produce planting material for cropping and restoration of affected areas. To improve cost efficiency of the micropropagation protocol, in vitro rhizome structures were induced using in vitro-maintained plants as explants under three quantities of sucrose, four of benzyl aminopurine - BAP and four of abscisic acid - ABA supplied in $\mathrm{MS}$ with (in $\mathrm{mg} \mathrm{L}^{-1}$ ) myo-inositol (100), thiamine $\mathrm{HCL}$ $(0.4)$, and solidified with Phytagel ${ }^{\circledR}$ (3.000). Treatments (48) were distributed using a complete randomized design with six replicates per treatment. Cultures were stored during eight weeks at $25{ }^{\circ} \mathrm{C}$ with $12 \mathrm{~h}$ photoperiod (40 umol photons $\mathrm{m}^{-2} \mathrm{~s}^{-1}$ ) provided by with cold fluorescent lamps. Statistical differences were observed with respect to number of rhizomes and rhizome length as a result of three factor interaction. Ex vitro plantlet recovery occurred at highest percentage from rhizomes developed in media supplied with sucrose at $263000 \mu \mathrm{M}$ combined with 4.44 and $8.88 \mu \mathrm{M}$ BAP. Data evidenced the possibility of inducing in vitro rhizome growth from arrow cane explants to use them as a way for propagation and plant conservation.
\end{abstract}

Key words: Arrow cane, micropropagation, in vitro, rhizome formation, PGR.

\footnotetext{
1* Ph.D Docente Universidad de Córdoba. Carrera 6 N. 76-103. Montería. Colombia. iesuarez@correo.unicordoba.edu.co

${ }^{2}$ Licenciado en Ciencias Naturales y Educación Ambiental. Carrera 6 N. 76-103. Universidad de Córdoba. Montería. Colombia.

${ }^{3}$ Licenciada en Ciencias Naturales y Educación Ambiental. Grupo Biotecnología Vegetal. Carrera 6 N. 76-103. Universidad de Córdoba. Montería. Colombia.
} 


\section{INTRODUCCIÓN}

Habitat is always associated with low wetlands and water strain where favors shore protection and reduce erosion habitat is always associated with low wetlands and water strain where favors shore protection and reduce erosion. Plants are used by Indians communities for house construction, arrows to haunt and fish, animal feeding from leaf tissue and as medicinal products; flavonoids and isoflavonoids such as (2R,3R)-2,3-trans$7,4^{\prime}$-dimethoxydihydroflavonol, $(2 \mathrm{R}, 3 \mathrm{~S}, 4 \mathrm{~S})$ 2,3-trans-3,4-cis-7, 4' -dimethoxy-3,4flavandiol,6-hydroxy-7,4'-dimethoxyflavone, 6,7,4'trimethoxyflavone, ferreirin, dihydrocajanin, dalbergioidin, dihydrobiochanin A and biochanin has been isolated from different organs of the plant (Benavides et al. 2007). Studies reported the use of G. sagitatum plants as a mechanism to detoxify soils contaminated with $\mathrm{Hg}, \mathrm{Pb}, \mathrm{Cr}$ and $\mathrm{Cd}$ via phytoremediation of landfill leachate (Ortega-Ortega et al. 2011; Madera-Parra et al. 2015 a,b).

G. sagitatum plants are canes with up to $10 \mathrm{~m}$ length stems and $2-8 \mathrm{~cm}$ diameter. Leaves are linear cauline, leaf blades up to $2 \mathrm{~m}$ length and $8 \mathrm{~cm}$ wide with scabrous margins. Inflorescence is a 1-1.5 $\mathrm{m}$ long panicle with $3 \mathrm{~mm}$ dioecious flowers in spikelet and $1 \mathrm{~mm}$ long brown seeds. Stems grow from rhizomes that develop horizontally up to $10 \mathrm{~m}$ from the main stem; a single stem can hold up to 200 leaves in a life cycle that ends when flowers emerge and seed. Propagation occurs by sexual and clonal way; however, under local conditions seeds are highly inviable; therefore, clonal propagation by rhizome originated shoots is the main propagation method in natural conditions; rhizomes grow developing an underground stem net that work as propagation system into new territories (Aramendiz et al. 2005; Clayton et al. 2015). In Colombia, central nerve of G. sagitatum leaves are the main fiber source for traditional Colombian craftsmanship made by Zenu communities in the North Caribbean planes since pre Columbian times, perpetuating legacy and cultural aboriginal traditions.

Production of large quantities of clonal planting material had been a main constrain for commercial cultivation of arrow cane plants; fiber extraction from natural population is endangering the species and sustainability of the craftsmanship activity along with negative impacts on the environment (Aramendiz et al. 2005). Micropropagation is a clonal propagation method used to produce large quantities of disease free planting material in short periods of time (Pati et al. 2006; Kumar et al. 2015). A micropropagation protocol to clonally propagate G. sagitatum using explants with pre-existing meristem have been developed and is currently used for massive plant production (Suárez et al. 2009; Pastrana y Suárez 2009). Lately, a double phase medium strategy has been implemented as a way to increase cost efficiency and plant quality of G. sagitatum micropropagated plants (López 2013). In vitro developing of modified stems such as tubers and rhizomes has been reported as a way for plant micropropagation and germplasm conservation in several plant species (Rayirath et al. 2011; Olivier et al. 2012; Muñiz-García et al. 2014; Badr et al. 2015). Hormone products such as ABA, BAP and increased sugar supply in the medium have been reported as elicitors for in vitro tuber and rhizome formation (Lema-Ruminska 2013; Ncube et al. 2014; Wang et al. 2015). G. sagitatum rhizome formation occurs naturally in the field; however, the in vitro induction and development of rhizome structures as a way for plant micropropagation and plantlet recovery is unknown. In the present research, combined $\mathrm{ABA}, \mathrm{BAP}$ and sugar treatments on in vitro G. sagitatum rhizome formation and plantlet recovery were evaluated. 


\section{MATERIALS AND METHODS}

Plant material was obtained from in vitro cultured arrow cane plants cv "Criolla". Plants were subcultured every four weeks, for more than a year, into fresh semisolid multiplication medium consisting of MS (Murashige y Skoog 1962) supplied with (in $\mathrm{mg} \mathrm{L}^{-1}$ ) myo-inositol (100), sucrose (30.000), thiamine $\mathrm{HCL}(0.4)$, benzilaminopurine (BAP) (0.5) and solidified with Phytagel $®$ (3.000) (Sigma Co.). Culture conditions were $25{ }^{\circ} \mathrm{C}$ with $12 \mathrm{~h}$ photoperiod $\left(40 \mu \mathrm{mol}\right.$ photons $\left.\mathrm{m}^{-2} \mathrm{~s}^{-1}\right)$ provided by with cold fluorescent lamps.

The $\mathrm{pH}$ of all media was adjusted to 5.7-5.8 prior to addition of gelling agent. Aliquots of $30 \mathrm{ml}$ were dispensed in $250 \mathrm{ml}$ glass flaks and covered with heavy duty aluminum foil. Media were sterilized in an Sterilof $\AA$ autoclave (Model 90/1 PGRgPr) at $120^{\circ} \mathrm{C}$ and 1.2 PSI during 15 min.

Three stem clusters obtained from in vitro maintained plants were established in semisolid MS with in ( $\mathrm{mg} \mathrm{L}^{-1}$ ) myo-inositol (100), thiamine $\mathrm{HCL} \quad(0.4)$ and solidified with Phytagel $\mathbb{R}$ (3.000) (Sigma Co.), and additionally supplied independently with three levels of sucrose $(87000,175000$ y $263000 \mu \mathrm{M})$ combined with five levels of abscisic acid (ABA) $(0.0 ; 1.89 ; 3.78$ y $7.77 \mu \mathrm{M})$ and five level of $\operatorname{BAP}(0.0 ; 2.22 ; 4.44$ y $8.88 \mu \mathrm{M})$. Cultures were established into 250 $\mathrm{ml}$ glass flasks with $30 \mathrm{ml}$ of medium. Flasks were covered with two-layers of heavy duty aluminum foil, sealed with Nescofilm $₫$ and maintained at $25{ }^{\circ} \mathrm{C}$ with 12 hour photoperiod $\left(40 \mu \mathrm{mol}\right.$ photons $\mathrm{m}^{-2} \mathrm{~s}^{-1}$ ) provided by withe cold fluorescent lamps. After eight weeks, every culture was taken from the flask inside the laminar flow hood and dissected using a SZX7 Olympus ${ }^{\circledR}$ microscope to register the number of developed structures, the type of structure developed and length of each structure.
A three-factor (sucrose, $\mathrm{ABA}$ and $\mathrm{BAP}$ ) experiment was designed with 48 treatments and 10 replicates per treatment for a total of 480 experimental units. Samples were distributed with a complete randomized design based on the model $Y_{i j i j k}=\mu+\tau_{i}+\beta_{j}+Y_{k}+(T \beta)_{i j}+(T y)$ ${ }_{i \mathrm{k}}+(\beta \mathrm{y})_{\mathrm{jk}}+(\mathrm{T} \beta \mathrm{y})_{\mathrm{ijk}}+\varepsilon_{\mathrm{ijk} j}$; were $\mu$ was the mean, $T \beta y$ were the levels of sucrose, BAP and ABA and $\varepsilon$ was the experimental error. Data were analyzed with an ANOVA ( $\alpha=0.05)$.

Vegetative structures grown from explant from the different treatments were transferred into 72 plug containers filled with peat as substrate. The containers were placed in a shade house with $20 \%$ light penetration and sprinkle irrigation with a frequency of three-2 minutes irrigation a day. Four weeks after transferring to ex vitro conditions, the number of plants was recorded and percentage of plantlet recovery calculated.

\section{RESULTS AND DISCUSSION}

Normal plants consisting of 2-3 stem clusters from a single growth point developed from explants cultured in medium used as control treatment (Figure 1a). In contrast, differentiated rhizomes were observed growing from explants cultured in treatments supplied with high sucrose content $(263000 \mu \mathrm{M})$ (Figure 1b) while no rhizome structures were observed growing from explants cultured, particularly but instead leafy-like growth was observed in treatments supplied with lower levels of sugar $(87 \mathrm{mM})$ and BAP (0.0 and $2.22 \mu \mathrm{m})$ (Figure 1c).

A rhizome is a specialized storage plant stem in which the main axis grows horizontally at or just below the ground surface. The structure has nodes and internodes with a leaf-like sheath attached at each node, adventitious roots and lateral shoots grow next to the node, and upright - growing shoots emerge either from the terminal tip or lateral nodes allowing the parent plant to clonally propagate ( $\mathrm{Li}$ et al. 2014). In the present study, structures 
emerging from the explants cultured in media with several sucrose/BAP/ABA combinations were consistent with rhizome characteristics showing lateral growth and emerging shoots at different points although no root formation was observed (Figure 1b). This response is consistent with the presence in the medium of BAP and $A B A$ and their effects, specifically for BAP, on lateral shoot growth promotion from axillary meristems and disruption of adventitious lateral root development, by accumulation, from the medium supply, of high levels of citokinins in cells of the root meristem such as lateral root cap, columnella initials and quiescent center cells resulting in an antagonistic interaction with endogenous auxin repressing its effects (Chan et al. 2013; Antoniadi et al. 2015; Bielach et al. $2012 \mathrm{a}, \mathrm{b})$.

The ANOVA allowed to detect that sucrose $(\operatorname{Pr}=<0.0001), \operatorname{BAP}(\operatorname{Pr}=<0.0001), \mathrm{ABA}(\mathrm{Pr}=$ $<0.0001)$ levels, and the interaction sucrose/ BAP/ABA $(\operatorname{Pr}=<0.0011)$ significantly affected the number of rhizome structures formed from explants cultured in the applied treatments (Table 1). The collected data shows that the highest number of rhizomes developed when explants were cultured in media supplied with $263000 \mu \mathrm{M}$ sucrose combined with 2.22 or $4.44 \mu \mathrm{M}$ BAP and 0 or $1.89 \mu \mathrm{M}$ ABA. Complete absence of $\mathrm{ABA}$ and $\mathrm{BAP}$, or combination of the highest amount of both PGRs resulted in no rhizome formation. Explants cultured in medium supplied with BAP at $2.22 \mu \mathrm{M}$ formed structures regardless of the amount of sucrose or ABA (Table 1).

Rhizomes in nature are modified underground stems used by plants to store starches and proteins, and allow herbaceous perennial plants to survive seasonally under adverse environmental conditions. Development of storage organs such as tubers has been extensively studied in species like Solanum tuberosum reporting that photoperiod, phytochrome regulation, flowering and starch accumulation genes, GA and ABA hormones, and several transcriptions factors are involved in tuber formation. Instead, rhizome is a complex poorly understood developmental process that depends on expression of genes controlled environmentally and endogenous factors (Cheng et al. 2013; Fischer et al. 2008; Abelenda et al. 2011; Tjaden et al. 1998; Kuipers et al. 1994). Recent studies have reported that like for tuber formation genes involved in photoperiod pathway (PHYB, CO, GI and FT), starch biosynthesis (SUS, UGPase, GBSS and SSS) and hormone signal transduction (GA, ABA, CTK, auxin, ethylene and JA) are related to rhizome formation and development (Yang et al. 2015). Additionally, studies on Sorghum spp and Miscanthus spp have identified rhizome enriched genes, supporting the genecontrolled developmental process of rhizome development (Jang et al. 2009; Kim et al 2014). On the other hand, sucrose has been observed to increase storage organ formation and size

Table 1. Mean number of in vitro Gynerium sagitatum Aubl. rhizome structures developed in media supplied with different sucrose, Benzil Aminopurine (BAP) and Abscisic Acid (ABA) amounts.

\begin{tabular}{|c|c|c|c|c|c|c|c|c|c|c|c|c|c|}
\hline \multicolumn{6}{|c|}{ Sucrose $(87000 \mu \mathrm{M})$} & \multicolumn{4}{|c|}{ Sucrose $(165000 \mu \mathrm{M})$} & \multicolumn{4}{|c|}{ Sucrose $(263000 \mu \mathrm{M})$} \\
\hline \multicolumn{6}{|c|}{ BAP $(\mu \mathrm{M})$} & \multicolumn{4}{|c|}{ BAP $(\mu \mathrm{M})$} & \multicolumn{4}{|c|}{ BAP $(\mu \mathrm{M})$} \\
\hline & & 0.00 & 2.20 & 4.44 & 8.88 & 0.00 & 2.20 & 4.44 & 8.88 & 0.00 & 2.20 & 4.44 & 8.88 \\
\hline & 0.00 & 0.00 & 2.17 & 0.00 & 0.17 & 0.00 & 1.00 & 2.00 & 4.33 & 0.00 & 6.00 & 4.83 & 2.50 \\
\hline ABA & 1.89 & 0.00 & 2.33 & 3.30 & 0.00 & 0.00 & 1.17 & 2.50 & 3.17 & 0.00 & 4.00 & 4.67 & 3.67 \\
\hline \multirow[t]{2}{*}{$(\mu \mathrm{M})$} & 3.78 & 0.00 & 0.17 & 0.00 & 0.00 & 0.00 & 2.17 & 1.00 & 0.00 & 0.50 & 1.67 & 3.67 & 0.00 \\
\hline & 7.57 & 0.00 & 1.33 & 0.00 & 0.00 & 1.00 & 2.67 & 0.33 & 0.00 & 1.00 & 2.50 & 0.50 & 0.00 \\
\hline
\end{tabular}

Effects $(\alpha=0.05)$ : Sucrose $\operatorname{Pr}<0.0001$, BAP $\operatorname{Pr}<0.0001, \mathrm{ABA} \operatorname{Pr}<0.0001$, sucrose $\times \mathrm{BAP} \times \mathrm{ABA} \operatorname{Pr}<0.0001$. 
in several species. In vitro formed Curcuma longa rhizomes were more numerous and accumulated a higher dry-mass when cultured in medium with increased sucrose supply (EIHawaz et al. 2015). In vitro cultures of Dioscorea rotunada and D. cayenensis developed more tubers when cultured in medium with 233000 $\mu \mathrm{M}$ sucrose compared to those cultured with $87000 \mu \mathrm{M}$ sucrose (Olivier et al. 2012; Dai et al. 2014). In the present research, the presence of BAP showed to be necessary for rhizome formation and increasing the sucrose level in the medium resulted in a higher frequency of rhizome formation; these results are consistent with previous in vitro rhizome formation reports.

The results of the ANOVA evidenced that sucrose, BAP, ABA and the interaction Sucrose/ BAP/ABA statistically affected the size of rhizomes emerging from the explants (Table 2). Explants cultured in medium supplied with $263000 \mu \mathrm{M}$ sucrose and $4.44 \mu \mathrm{M}$ BAP induced the longest structures, followed by those formed from explants cultured in 175000 $\mu \mathrm{M}$ sucrose, $2.22 \mu \mathrm{M}$ BAP and $7.57 \mu \mathrm{M}$ ABA. The smallest structures occurred when explants were cultured in $87000 \mu \mathrm{M}$ sucrose combined with $2.22 \mu \mathrm{M}$ BAP and $3.78 \mu \mathrm{M}$ ABA.

Starch accumulation has been associated with storage organ enlargement and swelling. In potato, tuber growth was found to be in coordination with accumulation of starch and in lotus rhizome enlargement is highly associated with starch biosynthesis (Abelenda et al. 2011). Starch synthesis initiates with sucrose conversion to fructose and DUPG by the gene SUS; the expression of this gene has been correlated with both potato tuber and lotus rhizome growth (Ogawa et al. 2009). Additionally, AGPase catalyzes the formation of ADP-glucose from G1P in plastids (chromoplasts, chloroplasts and amylopasts) of all starch-synthesizing tissues (Tetlow et al. 2004); lotus AGPases genes NNU_07115 and NNU_25036 were found associated with rhizome growth (Yang et al. 2015). In addition to carbohydrate accumulation, phytohormones such as GA, BAP, ABA, JA and ethylene have coordination with accumulation of starch been reported to play an important role in storage organs formation (Fernie And Willmitzer 2001). ABA has been found to promote tuber formation and reduce stolon length (Guo et al. 2010; Muñiz-Garcia et al. 2014); however, deficient ABA mutants showed ability to form tubers, indicating that $A B A$ is not essential for tuber formation. Instead, ABA seems to play a role as facilitator of other hormone functions and sugar accumulation (Rook et al. 2006; Sharma et al. 2004; Hu et al. 2012). Recently, auxin, ethylene, cytokinins and jasmonic acid related genes were found associated with rhizome formation and enlargement (Yang et al. 2015). In the present research, the collected data showed that increasing sucrose resulted in longer G. sagitatum rhizomes.

Table 2. Length mean $(\mathrm{mm})$ of in vitro Gynerium sagitatum Aubl. rhizome structuresdeveloped in media supplied with different sucrose, Benzil Aminopurine (BAP) and Abscisic Acid (ABA) amounts.

\begin{tabular}{|c|c|c|c|c|c|c|c|c|c|c|c|c|c|}
\hline \multicolumn{6}{|c|}{ Sucrose $(87000 \mu \mathrm{M})$} & \multicolumn{4}{|c|}{ Sucrose $(165000 \mu \mathrm{M})$} & \multicolumn{4}{|c|}{ Sucrose $(263000 \mu \mathrm{M})$} \\
\hline \multicolumn{6}{|c|}{ BAP $(\mu \mathrm{M})$} & \multicolumn{4}{|c|}{ BAP $(\mu \mathrm{M})$} & \multicolumn{4}{|c|}{ BAP $(\mu \mathrm{M})$} \\
\hline & & 0.00 & 2.20 & 4.44 & 8.88 & 0.00 & 2.20 & 4.44 & 8.88 & 0.00 & 2.20 & 4.44 & 8.88 \\
\hline & 0.00 & 0.00 & 4.78 & 0.00 & 0.52 & 0.00 & 2.67 & 3.28 & 3.15 & 0.00 & 3.90 & 6.48 & 1.45 \\
\hline ABA & 1.89 & 0.00 & 4.45 & 2.38 & 0.00 & 0.00 & 2.82 & 4.13 & 1.90 & 0.00 & 2.98 & 3.31 & 3.58 \\
\hline$(\mu \mathrm{M})$ & 3.78 & 0.00 & 0.36 & 0.00 & 0.00 & 0.00 & 3.70 & 2.75 & 0.00 & 0.50 & 2.40 & 5.33 & 0.00 \\
\hline & 7.57 & 1.00 & 3.02 & 0.00 & 0.00 & 1.00 & 5.38 & 0.40 & 0.00 & 1.00 & 4.25 & 0.70 & 0.00 \\
\hline
\end{tabular}

Effects $(\alpha=0.05)$ : Sucrose $\operatorname{Pr}<0.0001, \mathrm{BAP} \operatorname{Pr}<0.0001, \mathrm{ABA} \operatorname{Pr}<0.0001$, sucrose $\times \mathrm{BAP} \times \mathrm{ABA} \operatorname{Pr}<0.0001$. 
Plants developed only from in vitro grown rhizomes in media supplied with $263000 \mu \mathrm{M}$ sucrose with $4.4 \mu \mathrm{M}$ BAP at all ABA levels and with $8.8 \mu \mathrm{M}$ BAP at 0 and $1.89 \mu \mathrm{M}$ ABA. Only rhizomes cultured in $4.44 \mu \mathrm{M}$ BAP were able to regenerate plants at $165000 \mu \mathrm{M}$ sucrose. Structures formed from explants cultured in medium supplied with $263000 \mu \mathrm{M}$ sucrose combined with $4.44 \mu \mathrm{M}$ BAP allowed the highest number of plants recovered; while those cultured in medium with $165000 \mu \mathrm{M}$ sucrose combined with $4.44 \mu \mathrm{M}$ BAP and $1.89 \mu \mathrm{M}$ ABA resulted in the lowest number of plantlet recovered. The collected data showed that increased sucrose levels in the medium resulted in rhizomes with increased capacity for plant recovery (Table 3).

Table 3. Percentage of plantlet recovered from in vitro-developed rhizomes of $G$. sagitatum.

\begin{tabular}{|c|c|c|c|c|c|c|c|c|c|}
\hline \multicolumn{6}{|c|}{ Sucrose $(165000 \mu \mathrm{M})$} & \multicolumn{4}{|c|}{ Sucrose $(263000 \mu \mathrm{M})$} \\
\hline \multicolumn{6}{|c|}{ Benzil Aminopurine ( $\mu \mathrm{M})$} & \multicolumn{4}{|c|}{ Benzil Aminopurine $(\mu \mathrm{M})$} \\
\hline & & 0.00 & 2.20 & 4.44 & 8.88 & 0.00 & 2.20 & 4.44 & 8.88 \\
\hline & 0.00 & $*$ & $*$ & $*$ & $*$ & $*$ & $*$ & 38.00 & 33.00 \\
\hline & 1.89 & $*$ & $*$ & 13.00 & $*$ & $*$ & * & 21.00 & 36.00 \\
\hline$(\mu \mathrm{M})$ & 3.78 & $*$ & $*$ & * & $*$ & $*$ & $*$ & 18.00 & $*$ \\
\hline & 7.57 & $*$ & $*$ & $*$ & $*$ & $*$ & $*$ & 30.00 & $*$ \\
\hline
\end{tabular}

*No rhizome transferred to ex vitro conditions.

In vitro propagated plants and organs grown under low light radiation $\left(>60 \mu \mathrm{mol} \mathrm{m} \mathrm{m}^{-1} \mathrm{~s}^{-1}\right)$ are unable to activate photosynthesis, and therefore photoautotrophic nutrition is based on sugar supplied on the medium with starch accumulation occurring basically in plastids (Shin et al. 2009). Chloroplasts from in vitro grown tissues are underdeveloped and electron flow in the thylakoid membrane does not occur becoming incapable to convert light energy into chemical energy; additionally, stomatal conductance are low when plants are exposed to low light intensity (Yamori et al. 2010; Yamori et al. 2015; Huang et al. 2015). Since plants and organ are not photosynthetically active, organs transferred ex vitro conditions must have plenty of energy reserved to support new structures formation (leaves and roots) (Mollo et al. 2011; Badr et al. 2015). Because larger organs have more stored reserves (starch) they have more opportunity to successfully support growth of new emerging plants when transferred to ex vitro conditions.

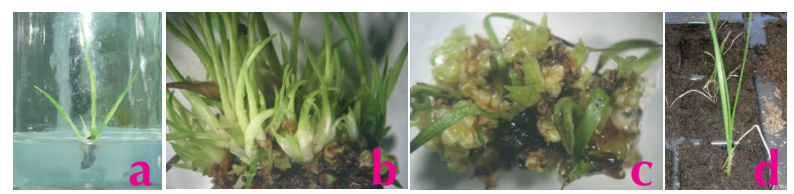

Figure 1. From left to right: a: Plants developed in control treatment, b: rhizomes from high sucrose medium, c: leafy tissues from explants cultured in low BAP and sucrose supplied medium, and $\mathrm{d}$ : recovered acclimatized plant.

\section{CONCLUSSIONS}

Rhizome structures from in vitro cultivated Gynerium sagitatum Aubl. explants is viable and potentially used for plant propagation and in vitro conservation.

Rhizome production from in vitro cultured Gynerium sagitatum Aubl. plants is statistically affected by sucrose/BAP/ABA interaction in the medium.

Combined supply of $26300 \mathrm{M}$ sucrose with 4.44 BAP in the culture medium resulted in most numerous larger rhizomes and higher survival rates for ex vitro acclimatized Gynerium sagitatum Aubl. plants.

\section{REFERENCES}

Abelenda, J., Navarro, C. and Prat, S. 2011. From the model to the crop: genes controlling tuber formation in potato. Current Opinion in Biotechnology 22 (2):287-292.

Antoniadi, I., Plackova. L., Simonovik. B., Dolezal. K., Turnbull. C., Ljung. K. and Novak, O. 2015. Cell-type-specific cytokinin distribution within the Arabidopsis primary root apex. Plant Cell 27(7):1967. 
Aramendiz, H., Espitia, M. and Robles, J. 2005. Colección, Colección, conservación, caracterización morfoagronómica y producción de semilla de caña flecha (Gynerium sagittatum Aubl.) del Caribe Colombiano. Informe final, Universidad de Córdoba, Facultad de Ciencias Agrícolas, Programa de Ingeniería Agronómica, Montería, 52-54, p. 118.

Badr, A., Angers, P. and Desjardins, Y. 2015. Comprehensive analysis of in vitro to ex vitro transition of tissue cultured potato plantlets grown with or without sucrose using metabolic profiling technique. Plant Cell Tissue and Organ Culture 122(2): 491-508.

Benavides, A., Bassarello, C., Montoro, P., Villegas, W., Piacente, S. and Pizza, C. 2007. Flavonoids and isoflavonoids from Gynerium sagittatum. Phytochemistry 68(9):1277-1284.

Bielach, A., Duclercq, J., Marhavy, P. and Benkova, E. 2012. Genetic approach towards the identification of auxincytokinin crosstalk components involved in root development. Philosophical transactions of the Royal Society of London. Serie B. Biological sciences 367(1595):1469-1478.

Bielach, A., Podlesakova, K., Marhavi, P., Duclercq, J., Cuesta, C., Muller, B., Grunewald, W., Tarkowsky, P. and Benkova, E. 2012. Spatiotemporal regulation of lateral root organogenesis in Arabidopsis by cytokinin. Plant Cell 24(10):3967-3981.

Chan, L., Ramireddy, E. and Schmulling, T. 2013. Lateral root formation and growth of Arabidopsis is redundantly regulated by cytokinin metabolism and signaling genes. Journal of Experimental Botany 64(16):5021-5032.
Cheng, L., Li, S., Yin, J., Li, L. and Chen, X. 2013. Genome-Wide analysis of differentially expressed genes relevant to rhizome formation in lotus root (Nelumbo nucifera Gaertn). PLos ONE. 8(6)1]: e67116. doi:10.1371/journal.pone.0067116 [25 de September de 2015]

Clayton, W., Vorontsova, M., Hartman, K. and Williamson, H. 2015. GrassBase The Online World Grass Flora. http:// www.kew.org/data/grasses-db.html. [10 September 2015].

Dai, Z., Meddar, M., Renaud, C., Merlin, I., Hilbert, G., Delrot, S. and Gomès, E. 2014. Long-term in vitro culture of grape berries and its application to assess the effects of sugar supply on anthocyanin accumulation. Journal of Experimental Botany 65(16):4665-4677.

El-Hawaz, R., Bridges, W. and Adelberg, J. 2015. In vitro growth of Curcuma longa L. in response to five mineral elements and plant density in fed-batch culture systems. PloS One 10(4), http://dx.doi. org/10.1371/journal.pone.0118912 [25 septiembre 2015].

Fernie, A. And Willmitzer, L. 2001. Molecular and biochemical triggers of potato tuber development. Plant Physiology 27(4):1459-465.

Fischer, L., Lipavska, H., Hausman, J. and Opatrny, Z. 2008. Morphological and molecular characterization of a spontaneously tuberizing potato mutant: an insight into the regulatory mechanisms of tuber induction. Bio Med Central Plant Biology 8(1):117. DOI:10.1186/14712229-8-117

Guo, L., Yu, L., Fan, Y., Lu, Neng., Yin, M., Zhang, F. and Yang, Q. 2010. Cloning and characterization of a potato TFL1 gene involved in tuberization regulation. Plant Cell Tissue and Organ Culture103(1):103-109. 
Hu, Y., Li, Y., Zhang, J., Liu, H., Tian, M. and Huang, Y. 2012. Binding of $A B I 4$ to a CACCG motif mediates the ABA-induced expression of the $\mathrm{ZmSSI}$ gene in maize (Zea mays L.) endospem. Journal of Experimental Botany 63(16):5979-5989.

Huang, W., Hu, H. and Zhang, Shi-Bao. 2015. Photorespiration plays an important role in the regulation of photosynthetic electron flow under fluctuating light in tobacco plants grown under full sunlight. Frontiers in Plant Science. 6: 1-9. DOI: 10.3389/fpls.2015.00621.

Jang, C., Kamps, T., Tang, H., Bowers, J., Lemke, C. and Paterson, A. 2009. Evolutionary fate of rhizome-specific genes in a nonrhizomatous Sorghum genotype. Heredity 102(3):266-273.

Kim, C., Lee, Tae-Ho., Guo, H., Chung, J., Paterson, A., Kim, D. and Lee, G. 2014. Sequencing of transcriptomes from two Miscanthus species reveals functional specificity in rhizomes, and clarifies evolutionary relationships. Bio Med Central Plant Biology. 14:1-10. DOI:10.1186/1471-2229-14-134.

Kuipers, A., Jacobsen, E., Visser, R. 1994. Formation and deposition of amylose in the potato-tuber starch granule are affected by the reduction of granulebound starch synthase gene-expression. The Plant cell 6(1):43-52.

Kumar, P., Selvarajan, R., Iskra-Caruana, M., Chabannes, M. and Hanna, R. 2015. Biology, etiology and control of virus diseases of banana and plantain. Advanced Virus Research 91: 229-269.

Lema-Ruminska, J., Goncerzewicz, K. and Gabriel, M. 2013. Influence of Abscisic Acid and Sucrose on Somatic Embryogenesis in Cactus Copiapoa tenuissima Ritt. Forma mostruosa. The Scientific World Journal, ID513985. DOI 10.1155/2013/513985. http:// dx.doi.org/10.1155/2013/513985 [25 septiembre 2015]
Li, X., Wang, J., Lin, J., Wang, Y. and Mu, C. 2014. Rhizomes help the forage grass Leymus chinensis to adapt to the Salt and Alkali Stresses. The Scientific World Journal. ID213401.15.http:// dx.doi.org/10.1155/2014/213401 [25 septiembre 2015]

López, C. 2013. Efecto del recipiente y medio de cultivo sobre la multiplicación in vitro de caña flecha (Gynerium sagitatum Aubl.). Tesis Licenciado en Ciencias Naturales y Medio Ambiente, Universidad de Córdoba, Montería.

Madera-Parra, C., Peña, M., Peña, E. and Lens, P. 2015. $\mathrm{Cr}(\mathrm{VI})$ and $\mathrm{COD}$ removal from landfill leachate by polyculture constructed wetland at a pilot scale. Environmental science and pollution research international 22(17):1280412815.

Madera-Parra, C., Peña-Salamanca, E., Peña, M., Rousseau, D. and Lens, P. 2015. Phytoremediation of Landfill Leachate with Colocasia esculenta, Gynerium sagittatum and Heliconia psittacorum in Constructed Wetlands. International Journal of Phytoremediation 17(1):16-24.

Mollo, L., Martins, M., Oliveira, V., Nievola, C., Figueiredo-Ribeiro, R. 2011. Effects of low temperature on growth and nonstructural carbohydrates of the imperial bromeliad Alcantarea imperialis cultured in vitro. Plant Cell Tissue and Organ Culture 107:141-149. DOI 10.1007/ s11240-011-9966-y

Muñiz-García, M., Stritzler, M. and Capiati, D. 2014. Heterologous expression of Arabidopsis ABF4 gene in potato enhances tuberization through ABA-GA crosstalk regulation. Planta 239(3):615631. 
Murashige, T and Skoog, F. 1962. A revised medium for rapid growth and bioassay with tobacco tissue culture. Physiologia Plantarum 15:473-497.

Ncube, B., Finnie, J. and Van, J. 2014. Carbonnitrogen ratio and in vitro assimilate partitioning patterns in Cyrtanthus guthrieae L. Plant Physiology and Biochemistry 74:246-254.

Ogawa, A., Audo, F., Toyofuku, K. and Kawashima, C. 2009. Sucrose Metabolism for the Development of Seminal Root in Maize Seedlings. Plant Production Science 12(1): 9-16.

Olivier, K., Honan, K., Anike, F., Agbo, G. and Dodo, H. 2012. In vitro induction of minitubers in yam (Dioscorea cayenensis D. rotundata complex). Plant Cell Tissue and Organ Culture 109(1):179-189.

Ortega-Ortega, R., Beltrán-Herrera, J. and Marrugo-Negrete, J. 2011. Acumulación de mercurio $(\mathrm{Hg})$ por caña flecha. Revista Colombiana Biotecnología 13(1):33-41.

Ortega-Ortega, R., Beltrán-Herrera, J. and Marrugo-Negrete, J. 2011. Acumulación de mercurio $(\mathrm{Hg})$ por caña flecha. Revista Colombiana Biotecnología 13(1):33-41.

Pastrana, I. y Suárez, I. 2009. Producción de plantas de caña flecha (Gynerium sagittatum) 'Criolla' a través de micropropagación. Revista Temas Agrarios 14(2):2-18.

Pati, P., Rath, S., Sharma, M., Sood, A. and Ahuja, P. 2006. In vitro propagation ofrose - a review. Biotechnology Advances 24(1):94-11.

Rayirath, U., Lada, R., Caldwell, C., Asiedu, S. and Sibley, K. 2011. Role of ethylene and jasmonic acid on rhizome induction and growth in rhubarb (Rheum rhabarbarum L.). Plant Cell Tissue and Organ Culture 105(2): 253-263.
Rook, F., Hadingham, S., Li, Y. Bevan, M. 2006. Sugar and ABA response pathways and the control of gene expression. Plant, Cell and Environment 29:426-434.

Sharma, P., Pandey, A., Bhattacharya, A., Nagar, $\mathbf{P}$ and Ahuja, P. 2004. ABA associated biochemical changes during somatic embryo development in Camellia sinensis (L.) O. Kuntze. Plant Physiology 161(11):1269-1276.

Shin, J., Kim, K., Kang, H., Zulfugarov, I., Bae, G., Lee, CH., Lee, D. and Choi, G. 2009. Phytochromes promote seedling light responses by inhibiting four negativelyacting phytochrome interacting factors. Proceedings of National Academy of Sciences USA. 106(18):7660-7665.

Suárez, I., Aramendiz, H. Pastrana, I. 2009. Micropropagación de Caña Flecha (Gynerium sagittatum Aubl.), Revista Facultad Nacional de Agronomía 62(2):51355143.

Tetlow, I., Morell, M. and Emes, M. 2004. Recent developments in understanding the regulation of starch metabolism in higher plants. Journal of experimental botany 55(406):2131-2145.

Tjaden, J., Mohlmann, T., Kampfenkel, K., Henrichs, G, Neuhaus, H. 1998. Altered plastidic ATP/ADP-transporter activity influences potato (Solanum tuberosum L.) tuber morphology, yield and composition of tuber starch. The Plant Journal 16(5):531-540.

Wang, Z., Shen, J., Ludewing, U. and Neumann, G. 2015. A re-assessment of sucrosesignaling involved in cluster-root formation and function in phosphatedeficient white lupin (Lupinus albus). Physiologia plantarum 154 (3):407-419. 
Yamori, W., Evans, J., Von Caemmerer S. 2010. Effects of growth and measurement light intensities on temperature dependence of $\mathrm{CO}_{2}$ assimilation rate in tobacco leaves. Plant Cell \&Environment 33(3):332-343.

Yamori, W., Shikanai, T. and Makino, A. 2015. Photosystem I cyclic electron flow via chloroplast $\mathrm{NADH}$ dehydrogenase-like complex performs a physiological role for photosynthesis at low light. Scientific Reports11(5):13908.
Yang, M., Zhu, L., Pan, C., Xu, L., Liu, Y., Ke, W. and Yang, P. 2015. Transcriptomic Analysis of the Regulation of Rhizome Formation in Temperate and Tropical Lotus (Nelumbo nucifera). Scientific Reports 5:13059. http://www.nature. com/articles/srep13059 DOi: 10.1038/ srep13059. [10 septiembre 2015]. 